\title{
Using Factor Analysis to Evaluate Sediment Quality of a Significant Mining Area in Turkey
}

\author{
Arzu Çiçek ${ }^{1}$, Esengül Köse ${ }^{2}$, Cem Tokatlı ${ }^{3 *}$ \\ ${ }^{1}$ Anadolu University, Applied Environmental Research Centre, Eskişehir, Turkey \\ ${ }^{2}$ Eskişehir Osmangazi University, Department of Environmental Protection and Control, Eskişehir, Turkey \\ ${ }^{3}$ Trakya University, İpsala Vocational School, Department of Laboratory Technology, İpsala/Edirne, Turkey
}

\author{
Received: 9 February 2018 \\ Accepted: 10 April 2018
}

\begin{abstract}
Statistical applications have been used to evaluate ecosystem quality in recent years. Factor analysis (FA) is a powerful multivariate statistical technique widely used to evaluate environmental pollution. Seydisuyu Stream Basin is located in the Central Anatolia Region of Turkey and it is one of the most important branches of the Sakarya River. There is a globally important boron mine on the basin and the system is exposed to intensive agricultural, domestic, and industrial pollution. The aim of this study is to evaluate the sediment quality of Seydisuyu Stream Basin using FA. For this purpose, some micro and macro element accumulations including $\mathrm{Cr}, \mathrm{Ni}, \mathrm{Cu}, \mathrm{Zn}, \mathrm{As}, \mathrm{B}, \mathrm{Pb}, \mathrm{Fe}, \mathrm{K}, \mathrm{Mn}$, and $\mathrm{Mg}$ in sediment were investigated by collected samples on the basin from 15 stations (including 3 from Çatören Dam Lake and 2 from the Kunduzlar Dam Lake) in summer 2012. According to FA results, three factors explained $90.95 \%$ of the total variance. The first factor (F1), the "urban-industrial factor," explained $47 \%$ of total variance; the second factor (F2), the "agricultural factor," explained $28.31 \%$ of total variance; and the third factor (F3), named the "geological-mining factor," explained $15.63 \%$ of total variance.
\end{abstract}

Keywords: Seydisuyu Stream Basin, sediment quality, factor analysis

\section{Introduction}

Inorganic pollutants can be strongly accumulated and biomagnified along water, sediment, and the aquatic food chain, and significant quantities of toxic metals are discharged into aquatic ecosystems [1]. Sediment may act as a sink of various contaminants and pose a

*e-mail: tokatlicem@gmail.com significant risk to water quality through complicated biogeochemical exchanges [2].

Multistatistical techniques, which help the interpretation of complex data matrices better understand the pollution status of the investigated ecosystems, are commonly used in large numbers of countries to evaluate the sediment quality of many different aquatic ecosystems [3, 4]. Factor analysis (FA), which is one of the most convenient multivariate statistical methods, is designed to reduce the number of variables to a small number of indices and help identify 
Table 1. Localities of selected stations.

\begin{tabular}{|c|c|c|c|}
\hline \multirow{2}{*}{ Stations } & \multirow{2}{*}{ Location } & \multicolumn{2}{|c|}{ Coordinates } \\
\cline { 3 - 4 } & & $\mathrm{x}$ & $\mathrm{y}$ \\
\hline 1 & Karaören Village & 291678 & 4344723 \\
\hline 2 & Kırka District & 286648 & 4350639 \\
\hline 3.1 & Çatören Dam Lake & 289800 & 4351019 \\
\hline 3.2 & Çatören Dam Lake & 288880 & 4351531 \\
\hline 3.3 & Çatören Dam Lake & 290654 & 4355433 \\
\hline 4 & Akin Village & 285940 & 4356774 \\
\hline 5.1 & Kunduzlar Dam Lake & 287229 & 4357142 \\
\hline 5.2 & Kunduzlar Dam Lake & 288269 & 4358041 \\
\hline 6 & Kesenler Village & 296117 & 4365244 \\
\hline 7 & Seyitgazi District & 300751 & 4369651 \\
\hline 8 & Yazıdere Village & 320690 & 4382501 \\
\hline 9 & Doğançayır & 320686 & 4382502 \\
\hline 10 & Hamidiye Village & 324123 & 4378834 \\
\hline 11 & Mesudiye District & 329283 & 4369106 \\
\hline 12 & Saithalimpaşa Village & 338431 & 4364451 \\
\hline & & & \\
\hline
\end{tabular}

the important components or factors for the investigated ecosystem [5-7].

Seydisuyu Stream Basin is located in Eskişehir Province of Turkey and includes one of the nation's most important borate deposits. In addition to the geologic structure of the basin, mining and industrial activities, and agricultural and domestic discharges are known as major pollution sources for the system $[8$, 9]. The present study applied FA to inorganic pollution data detected from Seydisuyu Stream Basin in order to evaluate sediment quality and observe the effective factors on this significant aquatic ecosystem.

\section{Material and Methods}

\section{Study Area and Sample Collection}

Seydisuyu Stream Basin, which is known to be exposed to significant organic and inorganic pollution, is located between the localities of 38.0851-39.0361 north latitude and 30.0161-31.0071 east longitude. The basin that has two significant reservoirs on the watershed contains many important agricultural lands and one of the most important mining areas (Kirka Boron Works) of Turkey [10].

Sediment samples were collected from 15 stations, including reservoirs (3 from Çatören Dam Lake and 2 from Kunduzlar Dam Lake) in summer 2012. Coordinates and localities of the selected stations are given in Table 1, and a map of the Seydisuyu Stream Basin, including the selected stations, is shown in Fig. 1.

\section{Chemical and Statistical Analysis}

Sediment samples were dried for $3 \mathrm{~h}$ at $105^{\circ} \mathrm{C}$ for element analyses. Then all sediment samples were placed $(0.25 \mathrm{~g}$ of each sample) in Pyrex reactors of a CEM Mars Xpress 5 microwave digestion unit.

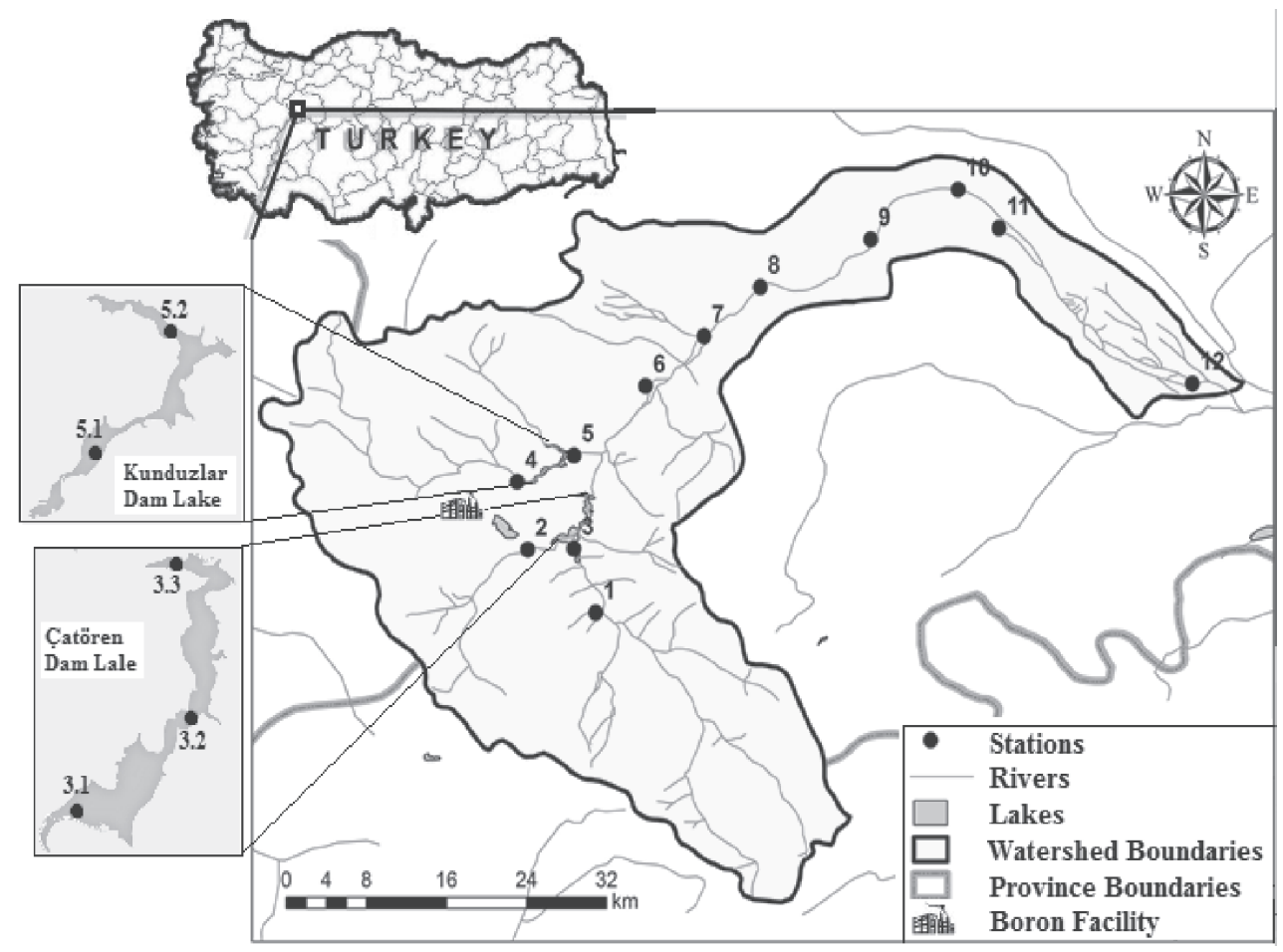

Fig. 1. Seydisuyu Stream Basin. 


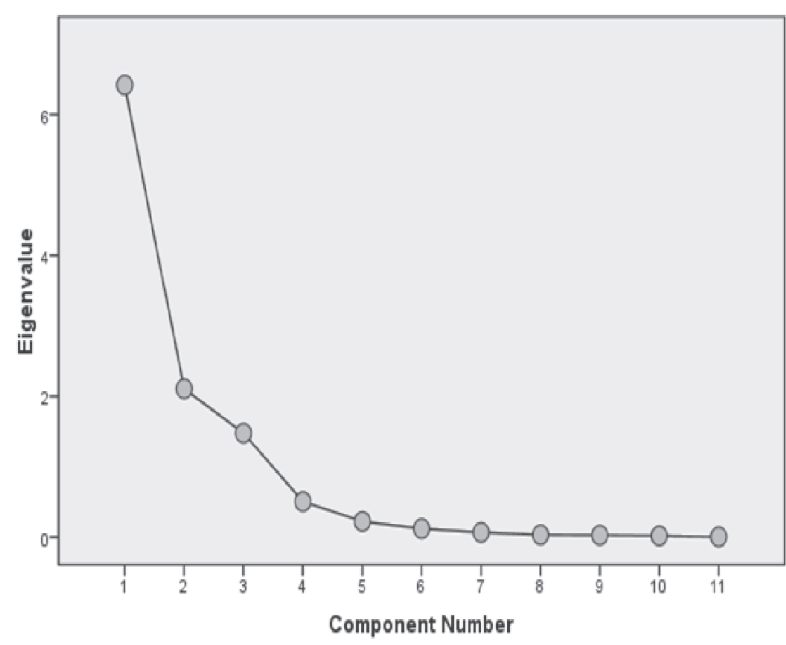

Fig. 2. Scree plot.

$\mathrm{HClO}_{4}: \mathrm{HNO}_{3}$ acids of $1: 3$ proportions were inserted in the reactors respectively. Samples were mineralized at $200^{\circ} \mathrm{C}$ for $30 \mathrm{~min}$. Afterward, the samples were filtered in such a way as to make their volumes to $100 \mathrm{ml}$ with ultra-pure distilled water.

Element levels were determined using inductively coupled plasma - optic emission spectrophotometry (Varian 720 ES) in the Environment Laboratory of Anadolu University. The element analyses were recorded as means triplicate measurements [11, 12].

FA was applied to the results to determine the effective variable factors on the Seydisuyu Stream Basin according to correlated variables using the "SPSS 17" package program.

\section{Results and Discussion}

Principal component analysis (PCA), which attempts to explain the variance of a large dataset of intercorrelated variables with a smaller set of independent variables, is a powerful pattern recognition tool. FA

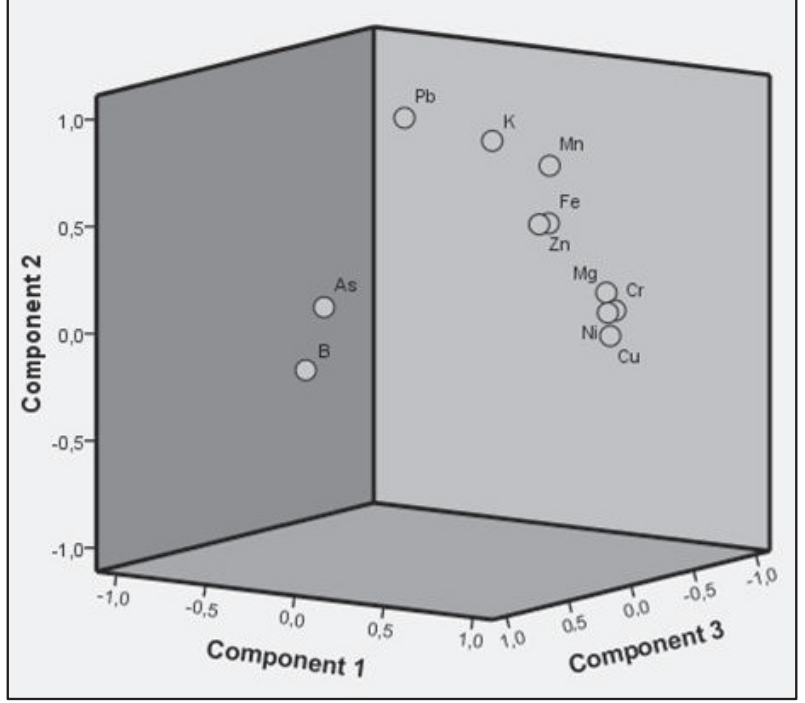

Fig. 4. Component plot in rotated space.

reduces the contribution of less significant variables and makes a new group of variables detected from PCA [3, 4, 13].

FA was used to determine the effective variable factors on sediment quality of Seydisuyu Stream Basin using correlated variables. A total of 11 variables were used to detect the variable factors $(n=15$ for all parameters). The result of the Kaiser Meyer Olkin test (KMO) that presents the measure of sampling adequacy was 0.64 . This value means that the sampling adequacy was at a good level for the present application $(>0.5)[2,14]$.

Eigenvalues higher than one were taken as criterion for evaluating the principal components required to explain the sources of variance in the dataset. According to rotated cumulative percentage variance, three factors explained $90 \%$ of the total variance. The FA scree plot is given in Fig. 2.

Liu et al. [14] classified the factor loadings according to loading values as "strong" $(>0.75)$,

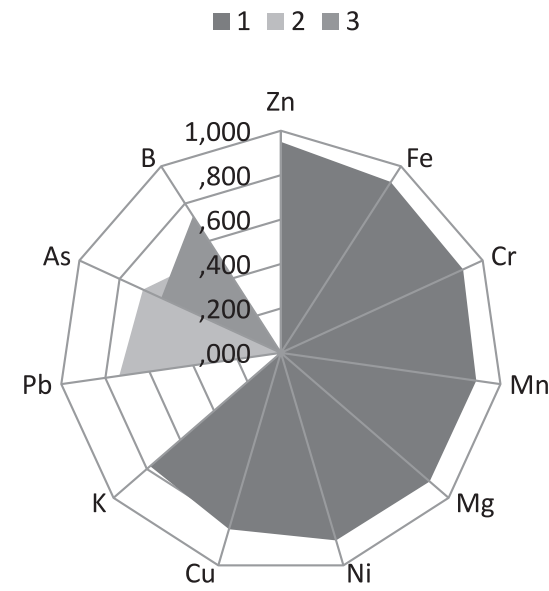

andustrial $\square$ Agricultural $\square$ Mining

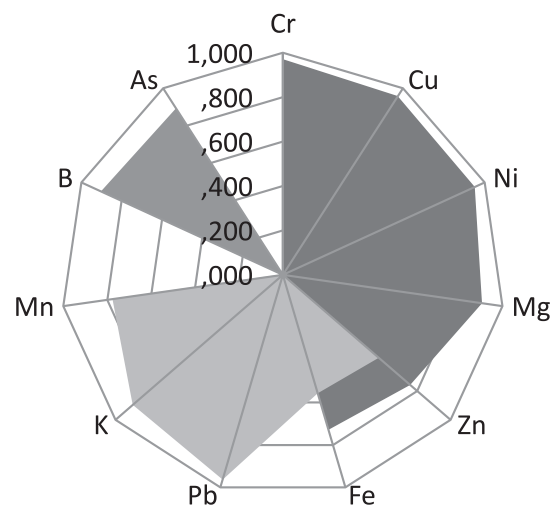

Fig. 3. Unrotated (left) and rotated (right) component matrix. 
"moderate" (0.75-0.50), and "weak" (0.50-0.30). Parameter loadings higher than 0.5 calculated before and after rotation for all components are given in Fig. 3. Also, component plots in a rotated space, which shows the related variables of three factors, is given in Fig. 4.

The first factor (F1), named "industrial factor," explained $47 \%$ of total variance and it was related to the variables of $\mathrm{Cr}, \mathrm{Cu}, \mathrm{Ni}, \mathrm{Mg}, \mathrm{Zn}, \mathrm{Fe}$, and $\mathrm{Mn}$. Fe and $\mathrm{Mn}$ parameters were moderate positive and $\mathrm{Cr}$, $\mathrm{Cu}, \mathrm{Ni}, \mathrm{Mg}$, and $\mathrm{Zn}$ parameters were strong positively loaded with this factor (Figs 3 and 4). Nickel and chromium, which occur naturally in the Earth's crust, may enter the environment as a result of natural processes and mostly by human activities. It is known that one of the most significant anthropogenic sources of these elements in surface sediments is industrial activity $[7,15,16]$. Industrial activities conducted around the basin could be the main source of chromium and nickel accumulations.

The second factor (F2), the "agricultural factor," explained $28 \%$ of total variance and it was related to the variables of $\mathrm{Zn}, \mathrm{Fe}, \mathrm{Pb}, \mathrm{K}$, and $\mathrm{Mn}$. $\mathrm{Zn}$ and $\mathrm{Fe}$ parameters were moderate positively and $\mathrm{Pb}, \mathrm{K}$, and Mn parameters were strongly positively loaded with this factor (Figs 3 and 4). Potassium, manganese, and zinc are three of the most abundant elements in the earth's crust and they are essential at low levels for all living organisms. The use of fertilizers in agricultural applications and urban runoff are two of the most common and significant factors on releases of these elements to the environment [17-18], and also the use of pesticides in agricultural applications containing significant quantities of lead [19-21]. Agricultural activities conducted around the basin could be a main source of potassium, manganese, zinc, and lead accumulations.

The third factor (F3), the "mining factor," explained $15 \%$ of total variance and it was related to the variables of As and B. All parameters were strongly positively loaded with this factor (Figs 3 and 4). Mining activities have an important place for the release of arsenic and boron to the environment from anthropogenic sources. Arsenic and boron are often correlated as they are both soluble minerals found in hydrothermal-volcanic deposits. And it is also known that boron content of geological structure significantly affects arsenic levels [22-23]. Turkey has $70 \%$ of the total boron reserve of the world, and the most important borate deposits of Turkey are located in the Seydisuyu Stream Basin (K1rka county of Eskişehir province) [25-7]. Mining activities conducted around the basin could be a main source of arsenic and boron accumulations.

\section{Conclusions}

In the present study, some trace and toxic element accumulation levels in sediment of Seydisuyu Stream Basin were evaluated using FA.
According to the results of FA, 3 statistically effective factors - urban-industrial, agricultural, and geological on element contents of sediments were identified using a large number of inorganic data. The results of this study reveal that industrial and agricultural runoff and mining activities conducted around the basin are the main risk factors for Seydisuyu Stream Basin.

In conclusion, multistatistical methods are necessary for a sophisticated evaluation because of obtained large numbers of data and the difficulty of interpretating all the parameters. Results of the present study reveal the benefits of statistical approaches and FA in abiotic components of the ecosystems.

\section{Acknowledgements}

The authors would like to thank Anadolu University, Turkey for its financial and technical support. This investigation also has been supported by project No. 1101F011 as accepted by Anadolu University, Commission of Scientific Research Projects.

\section{Conflict of Interest}

The authors declare no conflict of interest.

\section{References}

1. TOKATLI C., KÖSE E., ARSLAN N., ÇIÇEK A., EMIROĞLU Ö., DAYIOĞLU H. Ecosystem Quality Assessment of an Aquatic Habitat in a Globally Important Boron Reserve: Emet Stream Basin (Turkey). International Journal of Environment and Pollution, 59 (2/3/4), 116, 2016.

2. TOKATLI C. Bio - Ecological and Statistical Risk Assessment of Toxic Metals in Sediments of a Worldwide Important Wetland: Gala Lake National Park (Turkey). Archives of Environmental Protection, 43 (1), 34, 2017.

3. KÖSE E., EMIROĞLU Ö., ÇIÇEK A., TOKATLI C., BAŞKURT S., AKSU S. Sediment Quality Assessment in Porsuk Stream Basin (Turkey) from a Multi-Statistical Perspective. Pol. J. Environ. Stud. 27, (2), 747, 2018.

4. TOKATLI C. Use of Statistical Methods in Water Quality Assessment: A Case Study of Balkan Arboretum Area in Trakya University (Edirne, Turkey). Journal of Applied Biological Sciences, 7 (3), 79, 2013.

5. BUSICO G., CUOCO E., KAZAKIS N., COLOMBANI N., MASTROCICCO M., TEDESCO D., VOUDOURIS K. Multivariate Statistical Analysis to Characterize/ Discriminate Between Anthropogenic and Geogenic Trace Elements Occurrence in the Campania Plain, Southern Italy. Environmental Pollution 234, 260, 2018.

6. TOKATLI C., ÇIÇEK A., KÖSE E. Groundwater Quality of Türkmen Mountain (Turkey). Polish Journal of Environmental Studies, 22 (4), 1197, 2013.

7. TOKATLI C., ÇIÇEK A., EMIROĞLU Ö., ARSLAN N., KÖSE E., DAYIOĞLU H. Statistical Approaches to Evaluate The Aquatic Ecosystem Qualities of a Significant 
Mining Area: Emet Stream Basin (Turkey). Environmental Earth Sciences, 71 (5), 2185, 2014.

8. KÖSE E., TOKATLI C., ÇIÇEK A. Monitoring Stream Water Quality: A Statistical Evaluation. Polish Journal of Environmental Studies, 23 (5), 1637, 2014.

9. TOKATLI C., KÖSE E., ÇIÇEK A. Assessment of the Effects of Large Borate Deposits on Surface Water Quality by Multi Statistical Approaches: A Case Study of The Seydisuyu Stream (Turkey). Polish Journal of Environmental Studies, 23 (5), 1741, 2014.

10. ÇIÇEK A., BAKIŞ R., UĞURLUOĞLU A., KÖSE E., TOKATLI C. The Effects of Large Borate Deposits On Groundwater Quality Of Seydisuyu Basin (Turkey). Polish Journal of Environmental Studies, 22 (4), 1031, 2013.

11. ENVIRONMENTAL PROTECTION AGENCY (EPA) METHOD 3051. Microwave Assisted Acid Digestion of Sediments, Sludges, Soils, and Oils, 1998.

12. ENVIRONMENTAL PROTECTION AGENCY (EPA) METHOD 200.7. Determination of Metals And Trace Elements In Water And Wastes by Inductively Coupled Plasma-Atomic Emission Spectrometry, 2001.

13. KHALIT S.İ., SAMSUDIN M.S., AZID A., YUNUS K., ZAUDI M.A., SHARIFUDDIN S.S., HUSIN T.M. A Preliminary Study of Marine Water Quality Status Using Principal Component Analysis at Three Selected Mangrove Estuaries in East Coast Peninsular Malaysia. Malaysian Journal of Fundamental and Applied Sciences 13 (4), 764, 2017.

14. LIU C.W., LIN K.H., KUO Y.M. Application of factor analysis in the assessment of groundwater quality in a Blackfoot disease area in Taiwan. Science of the Total Environment, 313, 77, 2003.

15. ATSDR (Agency for Toxic Substances and Disease Registry). Toxicological Profile for Chromium. U.S. Department of Health and Human Services, 2000.

16. ATSDR (Agency for Toxic Substances and Disease Registry). Toxicological Profile for Nickel. U.S. Department of Health and Human Services, 2005.

17. HE Z., SHENTU J., YANG X., BALIGAR V.C., ZHANG T., STOFFELLA P.J. Heavy Metal Contamination of Soils: Sources, Indicators, and Assessment. Heavy
Metal Contamination of Soils: Sources, Indicators, and Assessment. Journal of Environmental Indicators, 9, 17, 2015.

18. ZÖRB C., SENBAYRAM M., PEITER E. Potassium in Agriculture - Status and Perspectives. Journal of Plant Physiology, Volume 171 (9), 656, 2014.

19. ATSDR (Agency for Toxic Substances and Disease Registry). Toxicological Profile for Lead. U.S. Department of Health and Human Services, 2007.

20. TOKATLI C., KÖSE E., ÇIÇEK A., EMIROĞLU Ö., ARSLAN N., DAYIOĞLU H. Lead Accumulations in Biotic and Abiotic Components of Emet Stream (Uluabat Lake Basin, Turkey). Pakistan Journal of Zoology, 44 (6), 1587, 2012

21. HOQUE M.A., BURGESS W.G., AHMED K.M. Integration of aquifer geology, groundwater flow and arsenic distribution in deltaic aquifers - A unifying concept. Hydrological Processes, 31 (11), 2095, 2017.

22. HOQUE M.A., BURGESS W.G., AHMED K.M. Integration of Aquifer Geology, Groundwater Flow and Arsenic Distribution in Deltaic Aquifers - A Unifying Concept. Hydrological Processes, 31 (11), 2095, 2017.

23. ATSDR (Agency for Toxic Substances and Disease Registry). Toxicological Profile for Arsenic. U.S. Department of Health and Human Services, 2007.

24. ATSDR (Agency for Toxic Substances and Disease Registry). Toxicological Profile for Boron. U.S. Department of Health and Human Services, 2010.

25. ATICI T., TOKATLI C., ÇIÇEK A. Non - Silica Algae of Seydisuyu Stream Basin (Eskişehir, Turkey). Biological Diversity and Conservation, 9 (3), 84, 2016.

26. ÇIÇEK A., TOKATLI C., KÖSE E., BAŞKURT S., EMIROĞLU Ö. Zinc and Copper Bioaccumulation Levels in Muscle, Gill and Liver Tissues of an Endemic Fish Species (Seydisuyu Stream Basin / Eskişehir / Turkey). Sigma Journal of Engineering and Natural Sciences, 35 (4), 751, 2017.

27. TOKATLI C., ÇIÇEK A., KÖSE E. Use of Bio Ecological Risk Indices to Evaluate the Sediment Quality of Seydisuyu Stream Basin. Iğdır University Journal of the Institute of Science and Technology, 7 (2), 267, 2017. 